\title{
Un exemple de technologie appropriée : les béliers hydrauliques d'Aignay-le-Duc
}

Jean-Luc Chevanne

\section{(2) OpenEdition \\ Journals}

Édition électronique

URL : https://journals.openedition.org/tc/824

DOI : $10.4000 /$ tc. 824

ISSN : 1952-420X

Éditeur

Éditions de l'EHESS

Édition imprimée

Date de publication : 1 octobre 1988

ISSN : 0248-6016

\section{Référence électronique}

Jean-Luc Chevanne, «Un exemple de technologie appropriée : les béliers hydrauliques d'Aignay-leDuc », Techniques \& Culture [En ligne], 11 | 1988, mis en ligne le 16 janvier 2006, consulté le 29

septembre 2022. URL : http://journals.openedition.org/tc/824 ; DOI : https://doi.org/10.4000/tc.824

Ce document a été généré automatiquement le 29 septembre 2022.

Tous droits réservés 


\section{Un exemple de technologie} appropriée : les béliers hydrauliques d'Aignay-le-Duc

Jean-Luc Chevanne 